\title{
Induction of Uncoupling Protein 3 Gene Expression in Skeletal Muscle of Preterm Newborns
}

\author{
PETR BRAUNER, PAVEL KOPECKÝ, PAVEL FLACHS, JOSEF RUFFER, VÁCLAV SEBROŇ \\ RICHARD PLAVKA, IVANA VÍTKOVÁ, JAROSLAV VORLÍČEK, AND JAN KOPECKÝ \\ Institute of Physiology, Academy of Sciences of the Czech Republic, Prague, Czech Republic [P.B., P.F., \\ J.V., J.K]; Division of Neonatology, Department of Obstetrics and Gynecology, [P.K., J.R., V.S., R.P.], \\ and Institute of Pathology [I.V.], General Hospital of the 1st Medical Faculty, Charles University, \\ Prague, Czech Republic
}

\begin{tabular}{|c|c|}
\hline \multicolumn{2}{|c|}{ ABSTRACT } \\
\hline $\begin{array}{l}\text { Prematurity is associated with delayed postnatal activation of } \\
\text { mitochondrial oxidative phosphorylation and impaired switch } \\
\text { from glycolytic to oxidative metabolism. Fatty acids (FA), which } \\
\text { represent a major energy substrate in mature muscle cells, are } \\
\text { engaged in the postnatal activation of genes of energy metabo- } \\
\text { lism and lipid oxidation. To understand the mechanism activating } \\
\text { mitochondria in human newborns, expression of the genes for } \\
\text { mitochondrial uncoupling proteins (UCP) was characterized in } \\
\text { autopsy samples of skeletal ( } n=28) \text { and cardiac ( } n=13 \text { ) } \\
\text { muscles of preterm neonates, who mostly died during the first } \\
\text { postnatal month, and two aborted fetuses. Transcripts levels for } \\
\text { UCP2, UCP3, and also for genes engaged in the transport of FA } \\
\text { between cytoplasm and mitochondria were measured using real- } \\
\text { time reverse transcriptase PCR. In accordance with studies in } \\
\text { mice, our results document postnatal induction of UCP3 gene } \\
\text { expression in skeletal muscle, involvement of nutritional FA in } \\
\text { the induction, and a role of UCP3 in mitochondrial FA oxidation. } \\
\text { They suggest impaired postnatal activation of UCP3 gene in }\end{array}$ & $\begin{array}{l}\text { neonates delivered before approximately } 26 \text { wk of gestation. } \\
\text { Mean levels of the UCP } 3 \text { transcript in skeletal muscle were by } \\
\text { two orders of magnitude higher than in the heart. In contrast to } \\
\text { UCP } 3 \text {, the UCP } 2 \text { gene was active in fetuses, and its expression } \\
\text { was not affected by nutrition. Our results support a role of UCP } 3 \\
\text { in postnatal activation of lipid oxidation in skeletal muscle and } \\
\text { suggest the involvement of UCP } 3 \text { in the delayed activation of } \\
\text { mitochondrial energy conversion in very immature preterm } \\
\text { neonates. (Pediatr Res 53: 691-697, 2003) }\end{array}$ \\
\hline
\end{tabular}

Postnatal switch of glycolytic to oxidative metabolism is of crucial importance for all mammalian neonates. Several studies (1-3) demonstrate the recruitment of energy conversion and ATP synthesis in mitochondria during the early postnatal period as well as insufficient maturation of this mechanism in premature newborns $(4,5)$. The recruitment of mitochondrial oxidative phosphorylation in the tissues of the newborns reflects changes in the hormonal status and also a shift from glucose to lipids as the major energy source during the early

Received July 26, 2002; accepted September 27, 2002.

Correspondence: Jan Kopecký, M.D., Ph.D., Institute of Physiology, Academy of Sciences of the Czech Republic, Vídeňská 1803, 14220 Prague, Czech Republic; e-mail: kopecky@biomed.cas.cz

Supported by the Internal Grant Agency of the Ministry of Health of the Czech Republic (grant NE/6430-5) and the March of Dimes Birth Defects Foundation (grant \#6-FY00-331).

DOI: 10.1203/01.PDR.0000054687.07095.0B postnatal period (6). However, nutritional FA serve not only as the source of energy but also as modifiers of the gene expression in many tissues (7). The effects of FA on gene expression in the newborns are of great significance with respect to the postnatal maturation of energy metabolism and mitochondrial functions. To understand the mechanisms underlying the adaptation of premature newborns to the extrauterine life, genes engaged in the control of energy metabolism must be identified. The role of the developmental status of the organism and of other possible external factors, such as nutrition, on the expression of the genes must be clarified.

UCP represent an important example of developmentally regulated genes participating in the control of mitochondrial energy conversion. They belong to a family of mitochondrial inner membrane transporters and are implicated in the regulation of the proton leak across the membrane. Thus, all UCP may lower the efficiency of mitochondrial ATP production; 
however, the functional roles of different UCP in cellular metabolism as well as the expression of the genes for UCP are mostly tissue specific (8). UCP1 is a characteristic marker of brown fat, where it has a profound thermogenic role (9). However, minute amounts of UCP1 have recently been found also in smooth muscle cells (10). UCP2 transcript is present in fetal tissues of rodents (11-13), and its level in both skeletal (12) and cardiac (14-16) muscle increases during the first postnatal weeks. In adult rodents, the UCP2 protein was detected in white adipose tissue, spleen, lung, and stomach $(8,17$, 18 ), and it was implicated in the regulation of reactive oxygen species production $(19,20)$. UCP3 is present only in skeletal muscle, heart, and brown fat (21-25). It is linked specifically to lipid metabolism (26-31), and indirect evidence suggests that this protein contributes to the control of energy expenditure in humans [for refs. see (23)]. Recent studies indicate that expression of UCP3 in both skeletal $(12,13)$ and heart $(14,16)$ muscle of rodents is negligible in fetuses and is switched on after birth. They also show that UCP3 gene expression is induced by FA (26) and that the postnatal induction of UCP3 gene in skeletal muscle of mice depends on the initiation of lipid intake during suckling (13). Therefore, UCP3 is an important candidate for the control of mitochondrial functions and the postnatal augmentation of lipid metabolism in muscles.

No data concerning the expression of the genes for UCP in developing muscles in humans have been published so far. Nothing is known about the functional significance of the UCP3 gene induction in human newborns. Therefore, the present research was designed to characterize the expression of the UCP3 gene in both skeletal and cardiac muscle during perinatal development in humans. To clarify possible links of uncoupling proteins to lipid metabolism in the developing muscles, the expression of the genes engaged in the transport of FA between mitochondria and cytoplasm, CPT-1 (32), and MTE-1 $(29,31)$ was analyzed. UCP2 gene expression was also characterized. Premature neonates, who died at different postnatal ages, and also aborted fetuses were studied.

\section{METHODS}

Human material. Samples of skeletal muscle (musculus quadriceps femoris) were obtained from 26 human newborns (gestational age at birth: median, $25 \mathrm{wk}$, range, 22-37 wk; birth weight: median $695 \mathrm{~g}$, range, 380-3210 g) during autopsy 2-3 $\mathrm{h}$ after death. Most of them were extremely low birth weight $(<1000 \mathrm{~g})$ newborns (20 cases; $77 \%$ of the newborns involved; Table 1). There were also six newborns with a birth weight $>1000 \mathrm{~g}$ (and gestational age $>28 \mathrm{wk}$ ). Two fetuses aborted at 23 wk of gestation were also included (cases Ab1 and Ab2; Table 1). A majority of the newborns died during the first postnatal month, the maximum length of survival was $140 \mathrm{~d}$ (Table 1). Samples of left atrial and ventricular myocardium were also collected from 13 newborns. Nutritional and other clinical data were recorded (Table 1). Infants born from mothers who suffered from endocrinological disorders or with drug abuse were not eligible for the study. For isolation of total RNA and characterization of gene expression (see below), samples were frozen and stored in liquid nitrogen, or they were preserved using RNAlater (Ambion, Austin, TX, U.S.A.) and stored at $-70^{\circ} \mathrm{C}$. The study protocol conforms to the ethical guidelines of the 1975 Declaration of Helsinki, and it was $a$ priori approved by the Committees of Medical Ethics at all the collaborating institutions. Informed consent was obtained from the parents.

RNA analysis. Total RNA was isolated using TRIzol Reagent (Invitrogen, Carlsbad, CA, U.S.A.). RNA (300 ng) was treated with RNase-free DNAse, and cDNA was obtained by reverse transcription with polyT primer using M-MLV reverse transcriptase (Invitrogen). Starting from 1/200 of cDNA obtained by the reverse transcription, real-time quantitative PCR (LightCycler instrument, Roche Molecular Biochemicals, Mannheim, Germany) was performed using QuantiTect SYBR Green PCR kit (QIAGEN, Valencia, CA, U.S.A.) with specific primers (Table 2). The PCR cycling profile consisted of an initial 15 -min activation at $95^{\circ} \mathrm{C}$, followed by 40 cycles of annealing $\left(20 \mathrm{~s}, 94^{\circ} \mathrm{C}\right)$, extension $\left(15-20 \mathrm{~s}, 60-62^{\circ} \mathrm{C}\right)$, and denaturation $\left(20 \mathrm{~s}, 72^{\circ} \mathrm{C}\right)$, with melting curve analysis for the final step. Values for each transcript represent means of at least three measurements. To correct for intersample variations in both the amount of RNA and the yield of the reverse transcription, concentrations of UCP2, UCP3, CPT-1, and MTE-1 transcripts were normalized using either elongation factor $\mathrm{EF}-1 \alpha$ or $\beta$-actin as housekeeping/maintenance genes (see "Results" and Ref. 33).

Statistics. Spearman correlation coefficient was used to evaluate the relationship between the gene expressions. Statistical significance of differences between groups was evaluated using the Mann-Whitney $U$ test. Differences among skeletal muscle, cardiac atrium, and cardiac ventricle were assessed by nonparametric Friedman test for one-way ANOVA model with post hoc tests using Wilcoxon matched-pairs test with Holm's adjustment of the significance level of individual comparisons between groups. The level of significance of all tests was set at $p=0.05$.

\section{RESULTS}

Quantification of gene expression. To measure the differences in gene expression, housekeeping/maintenance genes are used as internal standards for the normalization of the estimated transcript levels. The genes used for the normalization should turn on early in fetal life and stay on, and they should be equally expressed in different tissues (33). To optimize quantification of various transcripts in developing human muscles, we used two housekeeping/maintenance genes, EF-1 $\alpha$ and $\beta$-actin (33). In both the skeletal muscle and the heart samples, positive correlations between $\beta$-actin and EF- $1 \alpha$ transcript levels were found (Fig. 1). However, significant differences were detected in the levels of EF- $1 \alpha$ and $\beta$-actin transcripts among the tissues. When 13 newborns in which gene expression in the cardiac samples was characterized were compared (Table 1), the levels of EF-1 $\alpha$ in skeletal muscle, heart atrium, and heart ventricle were $6.4 \pm 2.1,14.5 \pm 4.1$, and $5.8 \pm 1.5$ arbitrary units, respectively. The corresponding values for $\beta$-actin were $14.6 \pm 5.2,68.8 \pm 22.7$, and $36.6 \pm$ 9.2. Because the differences in the mean values were smaller 
Table 1. Cases examined and levels of UCP2 and UCP3 transcripts in skeletal muscle

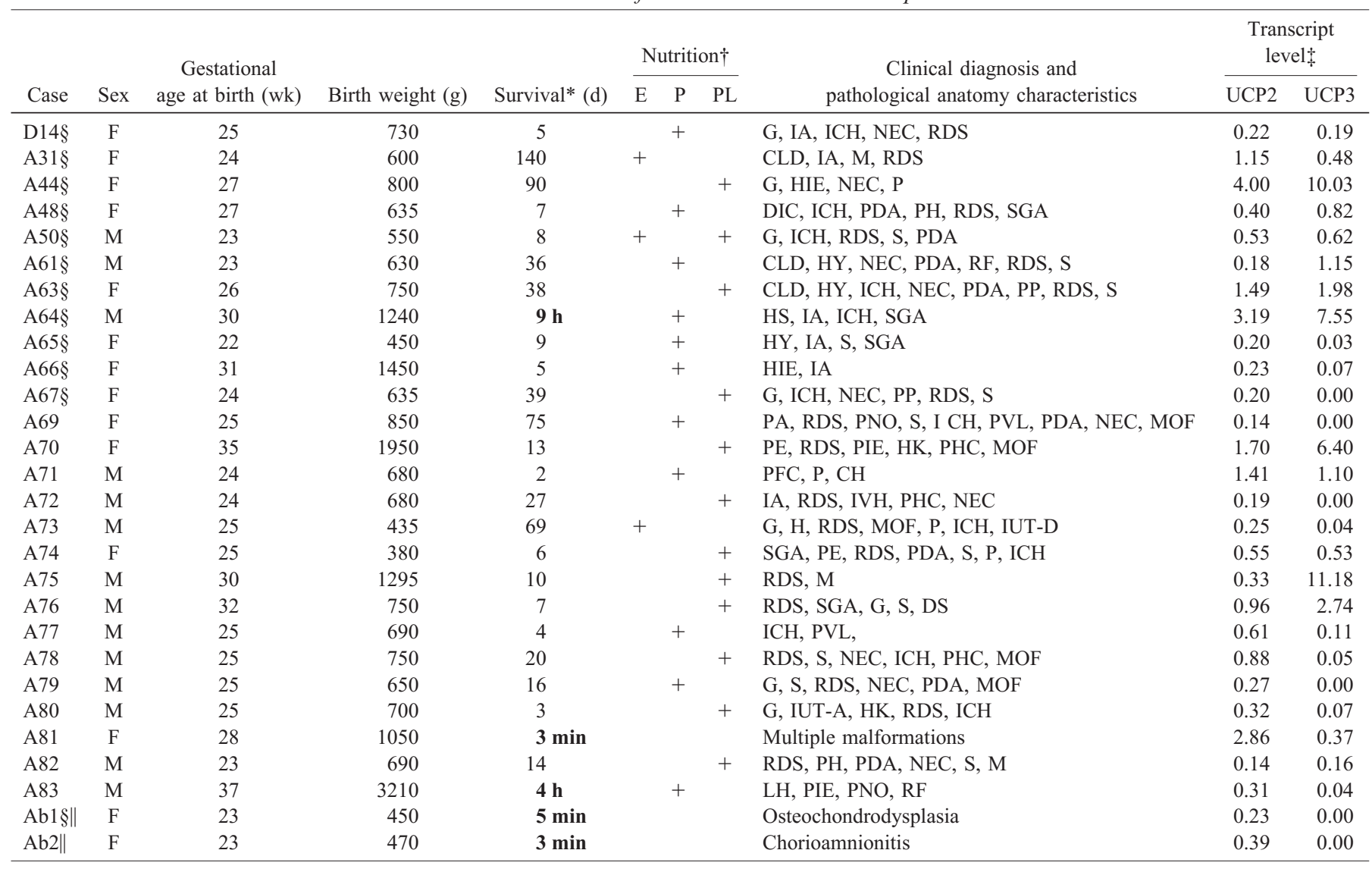

CHT, chromosomal translocation 45/14q21q; CLD, chronic lung disease; DIC, disseminated intravascular coagulation; G, gemini; HIE, hypoxic-ischemic encephalopathy; HK, hypertrophic cardiomyopathy; HS, hemorrhagic shock; HY, severe hypothermia (body temperature $<31{ }^{\circ} \mathrm{C}$ ) during the early postnatal period; IA, intrauterine asphyxia; ICH, intracranial hemorrhage; IUT-A, intrauterine transfusion acceptor; IUT-D, intrauterine transfusion donor; LH, lung hypoplasia; M, meningitis; DS, Down syndrome; MOF, multiorgan failure; NEC, necrotizing enterocolitis; P, pneumonia; PA, perinatal asphyxia; PDA, patent ductus arteriosus; PE, preeclampsia; PH, pulmonary hemorrhage; PHC, posthemorrhagic hydrocephalus; PIE, pulmonary emphysema; PNO, pneumothorax; PP, peripheral pancytopenia; RDS, respiratory distress syndrome; RF, respiratory failure; S, sepsis; SGA, small for gestational age; TGV, transposition of the great vessels.

* In days, except when indicated otherwise (in bold).

$\uparrow$ Type of nutrition during last $48 \mathrm{~h}$ before death: E, enteral nutrition (human milk or preterm formula); P, parenteral nutrition without lipids; PL, parenteral nutrition containing lipids (i.e. lipid emulsions containing both long- and medium-chain FA; the Lipofundin MCT/LCT 20\%, B. Braun Melsungen AG, Melsungen, Germany, or the Nutralipid MCT 20\% Emulsion, ICN Czech Republic, Prague).

$\ddagger$ Transcripts of UCP2 and UCP3 genes were quantified using real-time reverse transcriptase PCR and expressed relative to that of EF-1 $\alpha$ (see "Methods"). Values are means \pm SE. In all cases, the levels of CPT-1 and MTE-1 transcripts were also estimated (see Tables 3 and 4). In 13 newborns (A66, A67, A69, A70, A71, A72, A73, A74, A75, A76, A77, A81, and A82) the cardiac expression of UCP2, UCP3, CPT-1, and MTE-1 was also evaluated (see Fig. 1 and Table 4).

$\S$ Cases examined in previous studies 35,36 .

\| Abortion.

Table 2. Sequences of PCR primers

\begin{tabular}{llll}
\hline Gene & \multicolumn{1}{c}{ Sense primer $\left(5^{\prime}-3^{\prime}\right)$} & \multicolumn{1}{c}{ Antisense primer $\left(5^{\prime}-3^{\prime}\right)$} & GeneBank accession no. for cDNA \\
\hline EF-1 $\alpha$ & GAACCATCCAGGCCAAATAAGC & CCACCGCAACTGTCTGTCTCATA & AY043301.1 \\
$\beta$-actin & TGGTGGGCATGGGTCAGAAG & CCAGAGGCGTACAGGGATAGCAC & XM_037239.1 \\
UCP2 & CCTGCGGCTCGGACACATA & GGGGCACCTTTAATCAGCAACA & AF019409.1 \\
UCP3 & AGAACCATCGCCAGGGAGGAAGGA & CACCGGGGAGGCCACCACTGT & XM_006360.1 \\
CPT- ${ }^{*}$ & GCACGCCAGGCCTTCTTTAGC & GATGACCGCCTGGCACTGTTTT & U66828.1 \\
MTE- 1 & TGGGCAGCGGCATTTCAACTCC & TAATTCTTTCTCCCCTCAGCCCCATCC & NM_012332.1 \\
\hline
\end{tabular}

* The primers detect all known isoforms of transcripts of CPT- $1 \beta$ gene. They correspond to exons 11 and 14 .

with the EF- $1 \alpha$ gene than with $\beta$-actin and the EF- $1 \alpha$ gene showed only minimum changes in its expression during ontogeny (33), it was used for the normalization.

Gene expression in skeletal muscle. The main focus of the present study was on premature newborns who died as a result of various pathologic conditions associated with the immaturity. RNA was isolated from skeletal muscle for the quantification of UCP2, UCP3, CPT-1, and MTE-1 transcripts in all the newborns and fetuses involved in this study (Table 1). The expression data were analyzed to reveal the effects of gesta- 


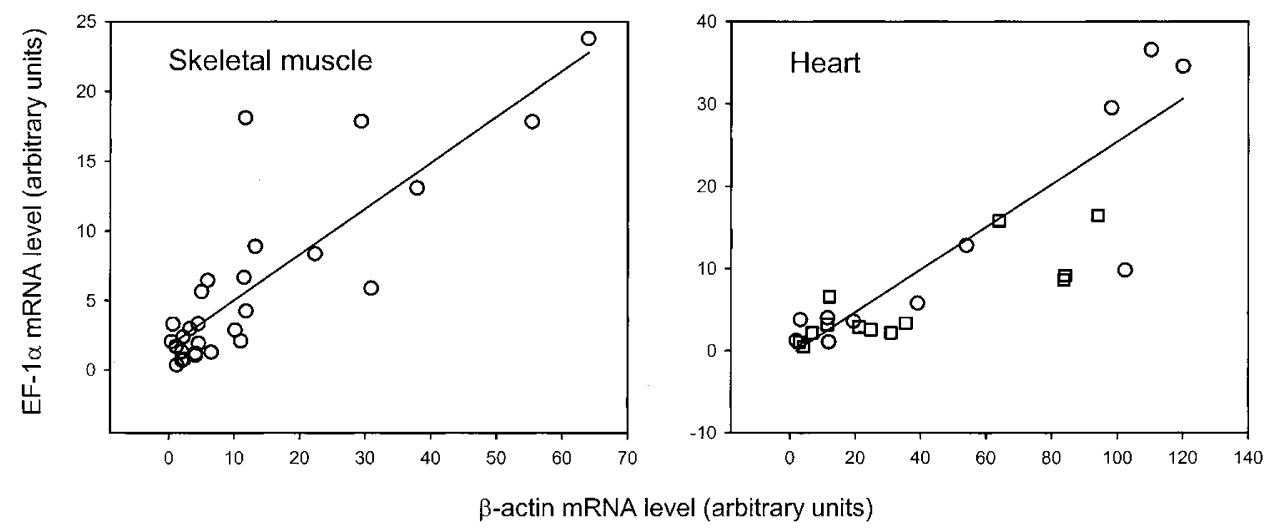

Figure 1. Correlations between concentrations of $\beta$-actin and EF-1 $\alpha$ transcript in skeletal muscle and heart. The concentrations were estimated in RNA isolated from musculus quadriceps femoris of two fetuses and 26 newborns (left; see Table 1), as well as in heart atrium (right, open circles) and ventricle (right, open squares) of 13 newborns (see note to Table 1). Positive correlations between transcript levels were found in both skeletal muscle $(R=0.78 ; p<0.001)$ and heart $(R=0.87 ; p<0.001)$.

tional age, length of survival (postnatal age), and nutrition during the last $48 \mathrm{~h}$ before death. Concerning the nutrition, it was studied whether the character of nutrition (i.e. enteral nutrition, parenteral nutrition without any lipids, parenteral nutrition containing lipids, or absence of the nutritional stimulus after birth; Table 1) could influence gene expression.

The UCP2 transcript was found in all the newborns and aborted fetuses. In contrast, in none of the fetuses, or in about $30 \%$ of the newborns, the UCP3 transcript could be detected or its levels were negligible compared with the newborns exhibiting the highest levels of expression (Table 1). In both UCP2 and UCP3 (Fig. 2), inspection of the data suggests an effect of the gestational age at birth on the transcript levels, as newborns with lower gestational age (and fetuses) seemed to have lower levels. Moreover, in the case of UCP3 but not UCP2, the effect of the type of nutrition was also apparent, namely in newborns born at gestational age $>25 \mathrm{wk}$ (Fig. 2). Therefore, statistical analysis was performed to compare gene expression in newborns with lower and higher gestational age, with the borderline set empirically between 25 and 26 wk (Fig. 2). The tendency to increase the expression of UCP2 with increasing gestational age at birth was not unequivocally supported by the statistical analysis of differences in the expression of the two groups $(n=10-16)$ of the newborns $(p=0.07)$. However, UCP3 transcript levels in newborns with gestational age at birth above 25 wk were significantly higher than in the newborns delivered at earlier stages of the intrauterine development $(p=0.02)$, namely when the newborns on parenteral nutrition containing lipids were compared ( $p<0.001$, Fig. 2). No effect of the length of survival on the expression of either UCP2 or UCP3 gene could be found (Fig. 2). No statistically significant correlation between the gestational age at birth and the length of survival was observed (not shown; for the data see Table 1). It was also found that within the group of neonates with higher gestational age at birth, the UCP 3 transcript levels were significantly higher in neonates receiving parenteral nutrition with lipids, compared with those receiving parenteral nutrition without lipids, or with all other neonates (Table 1 and Fig. 2). In fact, only one out of six newborns showing relatively high $\mathrm{UCP} 3$ transcript levels (i.e. $\geq 2$ arbitrary units) did
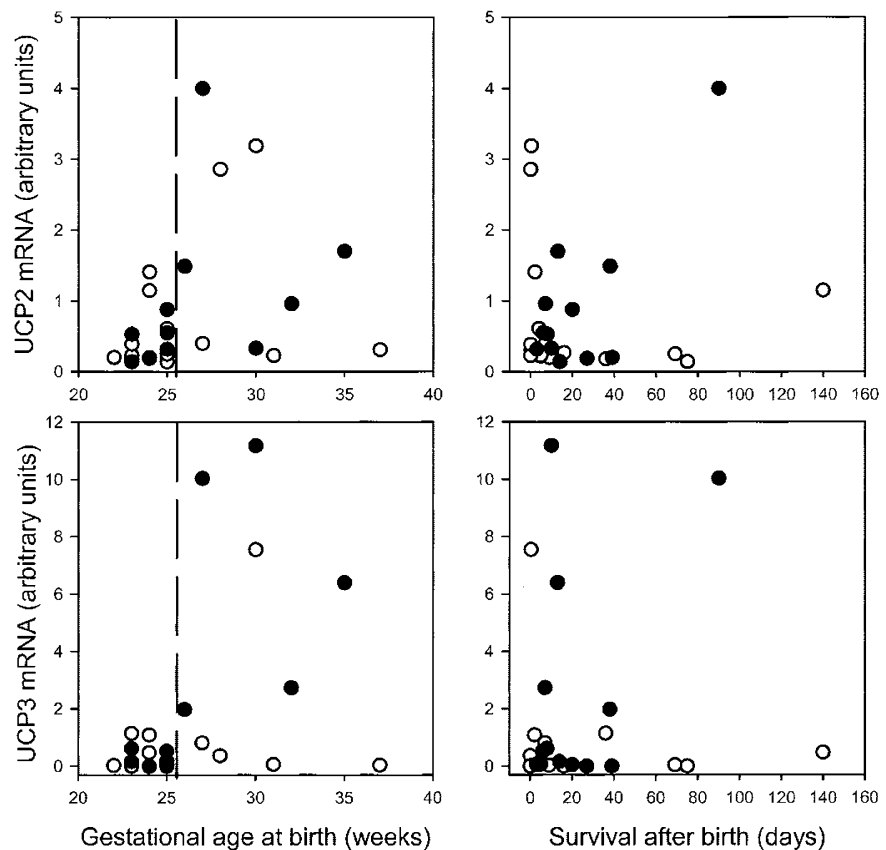

Figure 2. Expression of UCP2 and UCP3 genes normalized using EF- $1 \alpha$ in human skeletal muscle during early postnatal development. The levels of the UCP2 and UCP3 transcripts normalized using EF-1 $\alpha$ in skeletal muscle of 26 newborns and two fetuses (see Table 1) are plotted as a function of gestational age at birth and postnatal age. The type of nutrition during the last $48 \mathrm{~h}$ before death is also indicated. Filled symbols, parenteral nutrition containing lipids; open symbols, only enteral nutrition, or parenteral nutrition without lipids, or any nutrition, respectively (see Table 1). Dashed line separates age groups differing significantly in UCP3 gene expression (see "Results").

not receive any lipids in the nutrition (case A64; see Table 1 and Fig. 2). This effect of nutrition was not observed in neonates delivered before 26 wk of gestation (Table 1 and Fig. 2). Possible differences between the effect of enteral and parenteral nutrition (i.e. nutrition during the last $48 \mathrm{~h}$ before death) on UCP3 gene expression could not be evaluated, because all the neonates receiving enteral nutrition were born before 26 wk of gestation (Table 1; cases D14, A48, and A73). Expression of UCP2 was not significantly affected by the type of nutrition (Fig. 2). The same conclusions were made when $\beta$-actin (not shown) was used for the normalization of tran- 
script levels instead of EF-1 $\alpha$ (Table 1 and Fig. 2). The results indicate a postnatal induction of the UCP3 gene in skeletal muscle of human newborns and they suggest interplay between the effects of the gestational age at birth and nutrition in the control of the activity of the UCP3 gene.

In all the newborns and fetuses in our cohort (Table 1), the levels of the transcripts for CPT-1 and MTE-1 genes in skeletal muscle were also quantified. In all cases and with both genes, distinct levels of the transcripts were detected. In contrast to the expression of the gene for UCP3, no effect of the gestational age at birth or the postnatal age, or the type of nutrition could be observed (not shown). However, a positive correlation between the expression of the CPT-1 gene and that of all the other genes (i.e. UCP2, UCP3, and MTE-1) was found (Table 3). A positive correlation between UCP2 and UCP3 gene expression was also observed (Table 3). No correlation could be detected between the expression of MTE-1 and either of the genes for UCP.

Gene expression in the heart. Analysis of gene expression in cardiac muscle was performed in 13 newborns from our cohort (see note to Table 1) and the data were compared with the gene expression in the skeletal muscle in these newborns (Table 4). The transcript levels for UCP3 and MTE-1 were similar in atrium and ventricle, whereas the levels of UCP2 and CPT-1 were higher in the ventricle (about 2- and 4-fold, respectively) than in the atrium. The differences in transcript levels between heart and skeletal muscles were not greater than 3 -fold, except for UCP3. The mean values of UCP3 transcript levels were much lower (about 60 -fold) in the heart compared with skeletal muscle (Table 4), as also indicated by a comparison between the levels in skeletal and cardiac muscle of the

Table 3. Correlations between the levels of transcripts for UCP2, UCP3, CPT-1, and MTE-1 genes in skeletal muscle

\begin{tabular}{cccc}
\hline & UCP2 & UCP3 & CPT-1 \\
\hline UCP3 & & & \\
R & 0.65 & & \\
P & $\dagger$ & & \\
CPT-1 & & 0.39 & \\
R & 0.39 & $*$ & \\
P & $*$ & & 0.40 \\
MTE-1 & & -0.05 & $*$ \\
R & -0.15 & NS & $*$ \\
P & NS & & \\
\hline
\end{tabular}

Spearman rank order correlation test was used to perform pairwise comparison of transcript levels in skeletal muscle of human fetuses and neonates $(n=$ 27-28; see Table 1). NS, difference is not statistically significant $(p>0.05)$. $* p=0.01-0.05 ; \dagger p<0.01$. individual newborns. Thus, among 13 newborns characterized for the cardiac expression, the newborns A70 and A76 showed relatively high levels of UCP3 transcript in skeletal muscle (i.e. 6.40 and 2.74 arbitrary units, respectively; Table 1), whereas the levels of the UCP3 transcript in their hearts were $<0.004$ arbitrary units. In fact, the highest level of UCP3 transcript measured in heart was 0.13 arbitrary units (Fig. 3), i.e. much less than the levels in skeletal muscle (Fig. 2 and Table 4). In contrast to skeletal muscle (Fig. 2), no effect of either the gestational age at birth, or the nutrition, on the expression of UCP3 in the heart could be detected (Fig. 3).

\section{DISCUSSION}

This study reflects our continuous effort to comprehend the role of mitochondria and particularly UCP in postnatal maturation of tissues in human neonates. It is based on a unique collection of autopsy materials from premature neonates, mostly extremely low birth weight newborns (34-36). The present research is focused on mitochondrial UCP in developing human muscles. Our results demonstrate that gene expression could be characterized in autopsy samples of human newborn muscles using real-time quantitative PCR and that EF-1 $\alpha$ is a reliable housekeeping/maintenance gene for the normalization of the transcript levels. In accordance with studies in mice, showing the activation of UCP3 gene in skeletal muscle by lipid intake during suckling $(12,13)$, a statistically significant association between UCP3 transcript level in skeletal muscle and presence of lipids in parenteral nutrition could be observed in neonates born after $25 \mathrm{wk}$ of gestation (Fig. 2). Therefore, our data support the idea that circulating lipids are required for the postnatal activation of UCP3 gene expression in human skeletal muscle. They stress the importance of the lipid composition of nutrition for postnatal development (see Refs. 37-39).

The induction of the UCP3 gene may depend on the activation of its promoter (23) by FA via transcription factor(s), the peroxisome proliferator-activated receptor $\alpha$ (PPAR $\alpha$ ) and/or PPAR $\delta(12,40)$. However, other mechanisms may also be involved. Recent studies showed stimulation of the activity of both UCP2 and UCP3 genes in skeletal muscle by AMPactivated protein kinase, which reflects the energy status of the cell (41-43). Moreover, UCP3 gene promoter activity depends on $\mathrm{MyoD}$, the master regulator of differentiation program of muscle cells, and MyoD maybe responsible for preferential expression of UCP3 gene in differentiated muscle cells (44). It remains to be clarified whether, besides the lipid intake (and

Table 4. Levels of various transcripts in skeletal muscle, cardiac atrium, and ventricle

\begin{tabular}{lllll}
\hline & \multicolumn{4}{c}{ Transcript level (arbitrary units) } \\
\cline { 2 - 4 } \multicolumn{1}{c}{ Tissue } & UCP2 & UCP3 & CPT-1 & MTE-1 \\
\hline Skeletal muscle & $0.73 \pm 0.23$ & $1.746 \pm 0.932$ & $0.54 \pm 0.11$ & $0.67 \pm 0.15$ \\
Atrium & $0.23 \pm 0.06^{*}$ & $0.024 \pm 0.011^{*}$ & $0.47 \pm 0.08$ & $1.04 \pm 0.20^{*}$ \\
Ventricle & $0.49 \pm 0.06 \dagger$ & $0.036 \pm 0.009^{*}$ & $1.70 \pm 0.18^{*} \dagger$ & $1.20 \pm 0.24^{*}$ \\
\hline
\end{tabular}

Newborns in which gene expression in cardiac samples was characterized were compared ( $n=13$; see legend to Table 1$)$. Different transcripts were quantified using real-time reverse transcriptase PCR and are expressed relative to that of EF-1 $\alpha$ (see "Methods"). Values are means \pm SE.

* Significantly different from skeletal muscle.

$\dagger$ Significantly different from atrium. 


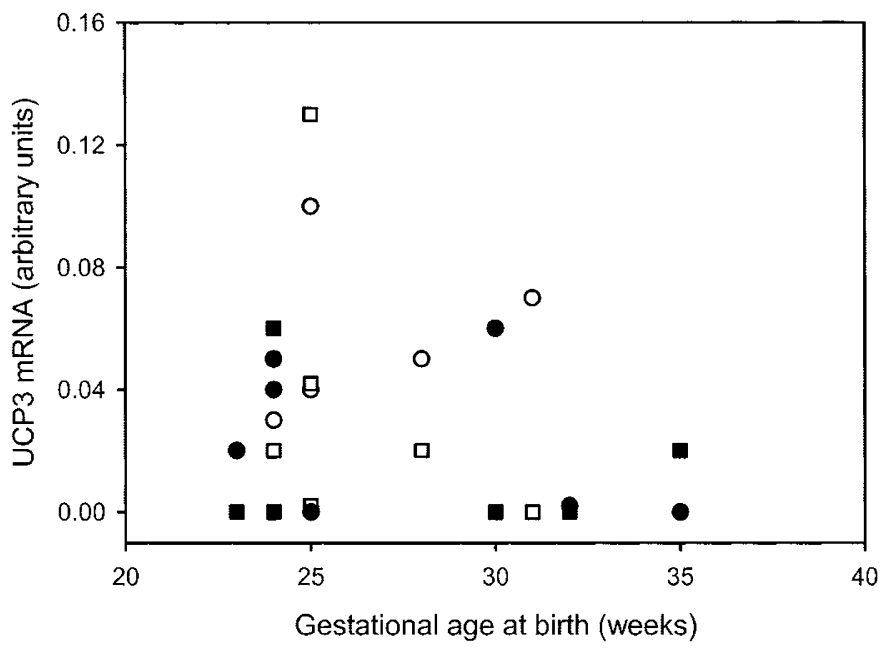

Figure 3. Expression of UCP3 gene normalized using EF- $1 \alpha$ in human heart as a function of gestational age at birth. Levels of UCP3 transcript normalized using EF- $1 \alpha$ in cardiac atrium (squares) and ventricle (circles) are plotted as a function of gestational age at birth. The type of nutrition during the last $48 \mathrm{~h}$ is indicated as in Figure 2 by open and filled symbols, respectively. Data from 13 newborns (see note to Table 1).

PPAR), the AMP-activated protein kinase or MyoD also contribute to the large variability in UCP3 gene expression among the neonates born after 25 wk of gestation.

In skeletal muscles of all the newborns delivered before 26 wk of gestation, relatively low UCP3 transcript levels were found. That UCP3 gene expression in skeletal muscle seems to depend on the gestational age at birth rather than on the postnatal (and postconceptional) age is striking. It is possible that the postnatal induction of the UCP3 gene is programmed during intrauterine development, and that appropriate conditions for the induction are not met by current clinical treatment of the very immature preterm newborns. Further studies on the influence of intrauterine factors on the postnatal development are clearly required.

Our results document substantial differences between activities of UCP2 and UCP3 genes in skeletal muscle during human perinatal development. The UCP2 transcript was detected in skeletal muscle of fetuses at 23 wk of gestation, whereas the UCP3 gene was silent during fetal life and became activated only after birth (see the expression of UCP2 and UCP3 genes in fetuses; Table 1, cases Ab1 and Ab2). Differential control of the expression of UCP2 and UCP3 genes was observed previously also in adult rodents $(45,46)$. Also, in contrast to UCP3, expression of UCP2 gene is mainly controlled translationally. This causes dissociation between the UCP2 transcript and protein level in most tissues, including muscle, where the content of the protein may be relatively low (18). Because UCP2 may decrease the formation of reactive oxygen species in mitochondria $(19,20)$, it may protect muscle cells against oxidative damage. UCP3 may also have a similar role (47). This role of UCP2 and UCP3 could be of special importance in premature neonates that are at high risk of the damage (48).

The postnatal induction of UCP3 gene is associated with maturation of the mechanism of oxidative phosphorylation, the major
ATP supplier in mammalian tissues (1-4). Several pieces of evidence strongly suggest involvement of UCP3 in lipid metabolism, namely in facilitating $\beta$-oxidation of FA in mitochondrial matrix $(26-28,31)$. It was also hypothesized that UCP3 served as a carrier exporting FA accumulated inside mitochondria to the cytoplasm. According to this hypothesis, positive correlation between UCP3 and MTE-1 transcript levels was expected $(29,31)$. However, no such correlation was observed in the skeletal muscle of human newborns in this study (Table 3). On the contrary, the positive correlation found between UCP3 and CPT-1 transcript levels in the muscles supports the stimulatory effect of UCP3 on lipid oxidation, because CPT-1 is involved in the transport of long-chain FA from cytoplasm to mitochondria (32). In agreement with the notion that lipid oxidation is required for normal glucose metabolism and insulin sensitivity of muscle cells (49), it may be speculated that induction of UCP3 in skeletal muscle of the newborn is required not only for the increase of lipid metabolism but also for insulin sensitivity and glucose uptake $(50,51)$.

Similarly, as in adult rodents $(21,22,24)$ and humans $(25)$, in human newborns UCP3 transcript levels were much lower in the heart compared with skeletal muscle. In contrast to human adults $(15,52,53), \mathrm{UCP} 2$ gene expression was similar in both types of muscle. Moreover, in the heart but not in skeletal muscle, similar levels of UCP3 transcript were detected in neonates born at various stages of gestation, and nutritional lipids seemed to be without any major effect on the cardiac UCP3 gene expression. Therefore, our data indicate substantial differences in the control of UCP3 gene expression between skeletal and heart muscles of human newborns. Further studies are required to quantify the UCP3 gene expression at the protein level using antibodies. However, reliable antibodies that would be specific for human UCP3 are not commercially available (54).

In conclusion, this study documents specific patterns of expression of genes engaged in the control of energy metabolism in skeletal muscle and heart, the postnatal induction of UCP3 gene expression in skeletal muscle, and the role of UCP3 in lipid oxidation in human newborns. The data are in accordance with the role of dietary lipids in the postnatal induction of UCP3 gene in skeletal muscle of human newborns, and indicate involvement of UCP3 in delayed activation of mitochondrial energy conversion in very immature preterm neonates. These observations are important for understanding the development of muscle energy metabolism in human neonates, and for developing new strategies for treatment of preterm newborns.

Acknowledgments. The authors thank Dr. Martin Rossmeisl and Prof. Arnošt Kotyk for critical reading of the manuscript.

\section{REFERENCES}

1. Izquierdo JM, Luis AM, Cuezva JM 1990 Postnatal mitochondrial differentiation in rat liver. J Biol Chem 265:9090-9097

2. Schonfeld P, Schild L, Bohnensack R 1996 Expression of the ADP/ATP carrier and expansion of the mitochondrial (ATP + ADP) pool contribute to postnatal maturation of the rat heart. Eur J Biochem 241:895-900

3. Schägger H, Noack H, Halangk W, Brandt U, von Jagow G 1995 Cytochrome-c oxidase in developing rat heart. Enzymic properties and amino-terminal sequences suggest identity of the fetal heart and the adult liver isoform. Eur $\mathrm{J}$ Biochem 230:235-241 
4. Valcarce C, Izquierdo JM, Chamorro M, Cuezva JM 1994 Mammalian adaptation to extrauterine environment: mitochondrial functional impairment caused by prematurity. Biochem J 303:855-862

5. Sperl W, Sengers RC, Trijbels JM, Ruitenbeek W, Doesburg WH, Smeitink JA Kollee LA, Boon JM 1992 Enzyme activities of the mitochondrial energy generating system in skeletal muscle tissue of preterm and full-term neonates. Ann Clin Biochem 29:638-645

6. Ferré P, Decaux JF, Issad T, Girard J 1986 Changes in energy metabolism during the suckling and weaning period in the newborn. Reprod Nutr Dev 26:619-631

7. Duplus E, Forest C 2002 Is there a single mechanism for fatty acid regulation of gene transcription? Biochem Pharmacol 64:893-901

8. Ricquier D, Bouillaud F 2000 The uncoupling protein homologues: UCP1, UCP2 UCP3, StUCP and AtUCP. Biochem J 345:161-179

9. Enerbäck S, Jacobsson A, Simpson EM, Guerra C, Yamashita H, Harper ME, Kozak LP 1997 Mice lacking mitochondrial uncoupling protein are cold-sensitive but not obese. Nature 387:90-94

10. Nibbelink M, Moulin K, Arnaud E, Duval C, Pénicaud L, Casteilla L 2001 Brown fa UCP1 is specifically expressed in uterine longitudinal smooth muscle cells. J Bio Chem 276:47291-47295

11. Hodný Z, Kolářová P, Rossmeisl M, Horáková M, Nibbelink M, Pénicaud L, Casteilla L, Kopecký J 1998 High expression of uncoupling protein 2 in foetal liver. FEBS Lett $425 \cdot 185-190$

12. Brun S, Carmona MC, Mampel T, Viñas O, Giralt M, Iglesias R, Villarroya F 1999 Activators of peroxisome proliferator-activated receptor- $\alpha$ induce the expression of the uncoupling protein-3 gene in skeletal muscle. Diabetes 48:1217-1222

13. Brun S, Carmona MC, Mampel T, Viñas O, Giralt M, Iglesias R, Villarroya F 1999 Uncoupling protein-3 gene expression in skeletal muscle during development is regulated by nutritional factors that alter circulating non-esterified fatty acids. FEBS Lett 453:205-209

14. Teshima Y, Saikawa T, Yonemochi H, Hidaka S, Yoshimatsu H, Sakata T 1999 Alteration of heart uncoupling protein-2 mRNA regulated by sympathetic nerve and triiodothyronine during postnatal period in rats. Biochim Biophys Acta 1448:409-415

15. van der Lee KAJM, Willemsen PHM, van der Vusse GJ, van Bilsen M 2000 Effects of fatty acids on uncoupling protein-2 expression in the rat heart. FASEB J 14:495-502

16. Langdown ML, Smith ND, Sugden MC, Holness MJ 2001 Excessive glucocorticoid exposure during late intrauterine development modulates the expression of cardiac uncoupling proteins in adult hypertensive male offspring. Pflugers Arch 442:248-255

17. Yu XX, Mao W, Zhong A, Schow P, Brush J, Sherwood SW, Adams SH, Pan G 2000 Characterization of novel UCP5/BMCP1 isoforms and differential regulation of UCP4 and UCP5 expression through dietary or temperature manipulation. FASEB 14:1611-1618

18. Pecqueur C, Alves-Guerra MC, Gelly C, Lévi-Meyrueis C, Couplan E, Collins S, Ricquier D, Bouillaud F, Miroux B 2001 Uncoupling Protein 2 in vivo distribution, induction upon oxidative stress and evidence for translational regulation. J Biol Chem 276:8705-8712

19. Arsenijevic D, Onuma H, Pecqueur C, Raimbault S, Manning BS, Miroux B, Couplan E, Alves-Guerra MC, Goubern M, Surwit R, Bouillaud F, Richard D, Collins S, Ricquier D 2000 Disruption of the uncoupling protein-2 gene in mice reveals a role in immunity and reactive oxygen species production. Nat Genet 26:435-439

20. Nègre-Salvayre A, Hirtz C, Carrera G, Cazenave R, Troly M, Salvayre R, Pénicaud L, Casteilla L 1997 A role for uncoupling protein-2 as a regulator of mitochondria hydrogen peroxide generation. FASEB J 11:809-816

21. Vidal-Puig A, Solanes G, Grujic D, Flier JS, Lowell BB 1997 UCP3: an uncoupling homologue expressed preferentially and abundantly in skeletal muscle and brown adipose tissue. Biochem Biophys Res Commun 235:79-82

22. Matsuda J, Hosoda K, Itoh H, Son C, Doi K, Tanaka T, Fukunage Y, Inoue G, Nishimura H, Yoshimasa Y, Yamori Y, Nakao K 1997 Cloning of rat uncoupling protein-3 and uncoupling protein-2 cDNAs: their gene expression in rats fed high-fat diet. FEBS Lett 418:200-204

23. Esterbauer H, Oberkofler H, Krempler F, Strosberg AD, Patsch W 2000 The uncoupling protein-3 gene is transcribed from tissue-specific promoters in humans but not in rodents. J Biol Chem 275:36394-36399

24. Gong DW, He Y, Karas M, Reitman M 1997 Uncoupling protein-3 is a mediator of thermogenesis regulated by thyroid hormone, beta3-adrenergic agonists, and leptin. J Biol Chem 272:24129-24132

25. Boss O, Samec S, Paoloni-Giacobino A, Rossier C, Dulloo A, Seydoux J, Muzzin P, Giacobino JP 1997 Uncoupling protein-3: a new member of the mitochondrial carrie family with tissue-specific expression. FEBS Lett 408:39-42

26. Weigle DS, Selfridge LE, Schwartz MW, Seeleym RJ, Cummings DE, Havel PJ, Kuijper JL, BeltrandelRio H 1998 Elevated free fatty acids induce uncoupling protein 3 expression in muscle: a potential explanation for the effect of fasting. Diabetes 47:298-302

27. Samec S, Seydoux J, Dulloo AG 1998 Role of UCP homologues in skeletal muscles and brown adipose tissue: mediators of thermogenesis or regulators of lipids as fuel substrates? FASEB J 12:715-724

28. García-Martínez C, Sibille B, Solanes G, Darimont C, Macé K, Villarroya F Gómez-Foix AM 2001 Overexpression of UCP3 in cultured human muscle lower mitochondrial membrane potential, raises ATP/ADP ratio, and favors fatty acid versus glucose oxidation. FASEB J 15:2033-2035

29. Himms-Hagen J, Harper ME 2001 Physiological role of UCP3 may be export of fatty acids from mitochondria when fatty acid oxidation predominates: a hypothesis. Exp Biol Med (Maywood) 226:78-84
30. Cadenas S, Buckingham JA, Samec S, Seydoux J, Din N, Dulloo AG, Brand MD 1999 UCP2 and UCP3 rise in starved rat skeletal muscle but mitochondrial proton conductance is unchanged. FEBS Lett 462:257-260

31. Clapham JC, Coulthard VH, Moore GB 2001 Concordant mRNA expression of UCP-3, but not UCP-2, with mitochondrial thioesterase-1 in brown adipose tissue and skeletal muscle in $\mathrm{db} / \mathrm{db}$ diabetic mice. Biochem Biophys Res Commun 287:1058-1062

32. Brown NF, Weis BC, Husti JE, Foster DW, McGarry JD 1995 Mitochondrial carnitine palmitoyltransferase I isoform switching in the developing rat heart. J Biol Chem 270:8952-8957

33. Warrington JA, Nair A, Mahadevappa M, Tsyganskaya M 2000 Comparison of human adult and fetal expression and identification of 535 housekeeping/maintenance genes. Physiol Genomics 2:143-147

34. Houšték J, Vízek K, Pavelka S, Kopecký J, Krejčová E, Heřmanská J, Cermáková S 1993 Type II iodothyronine 5'-deiodinase and uncoupling protein in brown adipose tissue of human newborns. J Clin Endocrinol Metab 77:382-387

35. Pavelka S, Kopecký P, Bendlová B, Štolba P, Vítková I, Vobruba V, Plavka R, Houštěk J, Kopecký J 1997 Tissue metabolism and plasma levels of thyroid hormones in critically ill very premature infants. Pediatr Res 42:812-818

36. Brauner P, Nibbelink M, Flachs P, Vítková I, Kopecky P, Mertelíková I, Janderová L, Pénicaud L, Casteilla L, Plavka R, Kopecky J 2001 Fast decline of hematopoiesis and uncoupling protein 2 content in human liver after birth: location of the protein in Kupffer cells. Pediatr Res 49:440-447

37. Rings EH, Minich DM, Vonk RJ, Stellaard F, Fetter WP, Verkade HJ 2002 Functiona development of fat absorption in term and preterm neonates strongly correlates with ability to absorb long-chain fatty acids from intestinal lumen. Pediatr Res 51:57-63

38. Genzel-Boroviczeny O, Hrboticky N 1996 Plasma values of polyunsaturated fatty acids in extremely low birth weight (ELBW) infants fed breast milk or formula very early in life. Eur J Med Res 1:495-498

39. Larque E, Demmelmair H, Koletzko B 2002 Perinatal supply and metabolism of long-chain polyunsaturated fatty acids: importance for the early development of the nervous system. Ann N Y Acad Sci 967:299-310

40. Muoio DM, MacLean PS, Lang DB, Li S, Houmard JA, Way JM, Winegar DA, Corton JC, Dohm GL, Kraus WE 2002 Fatty acid homeostasis and induction of lipid regulatory genes in skeletal muscles of peroxisome proliferator-activated receptor (PPAR) alpha knock-out mice. Evidence for compensatory regulation by PPAR delta. J Biol Chem 277:26089-26097

41. Pedersen SB, Lund S, Buhl ES, Richelsen B 2001 Insulin and contraction directly stimulate UCP2 and UCP3 mRNA expression in rat skeletal muscle in vitro. Biochem Biophys Res Commun 283:19-25

42. Zhou M, Lin BZ, Coughlin S, Vallega G, Pilch PF 2000 UCP-3 expression in skeletal muscle Effects of exercise, hypoxia, and AMP-activated protein kinase. Am J Physiol Endocrinol Metab 279:E622-E629

43. Minokoshi Y, Kim YB, Peroni OD, Fryer LG, Muller C, Carling D, Kahn BB 2002 Leptin stimulates fatty-acid oxidation by activating AMP-activated protein kinase. Nature 415:339-343

44. Solanes G, Pedraza N, Iglesias R, Giralt M, Villarroya F 2000 The human uncoupling protein-3 gene promoter requires MyoD and is induced by retinoic acid in muscle cells. FASEB J 14:2141-2143

45. Hidaka S, Kakuma T, Yoshimatsu H, Sakino H, Fukuchi S, Sakata T 1999 Streptozotocin treatment upregulates uncoupling protein 3 expression in the rat heart Diabetes 48:430-435

46. Kratky D, Strauss JG, Zechner R 2001 Tissue-specific activity of lipoprotein lipase in skeletal muscle regulates the expression of uncoupling protein 3 in transgenic mouse models. Biochem J 355:647-652

47. Vidal-Puig AJ, Grujic D, Zhang CY, Hagen T, Boss O, Ido Y, Szczepanik A, Wade J, Mootha V, Cortright R, Muoio DM, Lowell BB 2000 Energy metabolism in uncoupling protein 3 gene knockout mice. J Biol Chem 275:16258-16266

48. Buonocore G, Perrone S, Longini M, Vezzosi P, Marzocchi B, Paffetti P, Bracci R 2002 Oxidative stress in preterm neonates at birth and on the seventh day of life. Pediatr Res 52:46-49

49. Frayn KN, Summers LKM 1998 Substrate fluxes in skeletal muscle and white adipose tissue and their importance in the development of obesity. In: Kopelman PG, Stock MJ (eds) Clinical Obesity. Blackwell Science Ltd, Oxford, pp 129-157

50. Huppertz C, Fischer BM, Kim YB, Kotani K, Vidal-Puig A, Slieker LJ, Sloop KW, Lowell BB, Kahn BB 2001 Uncoupling protein 3 (UCP3) stimulates glucose uptake in muscle cells through a phosphoinositide 3-kinase-dependent mechanism. J Biol Chem 276:12520-12529

51. Clapham JC, Arch JR, Chapman H, Haynes A, Lister C, Moore GB, Piercy V, Carter SA, Lehner I, Smith SA, Beeley LJ, Godden RJ, Herrity N, Skehel M, Changani KK, Hockings PD, Reid DG, Squires SM, Hatcher J, Trail B, Latcham J, Rastan S, Harper AJ, Cadenas S, Buckingham JA, Brand MD, Abuin A 2000 Mice overexpressing human uncoupling protein-3 in skeletal muscle are hyperphagic and lean. Nature 406:415-418

52. Gimeno RE, Dembski M, Weng X, Deng N, Shyjan AW, Gimeno CJ, Iris F, Ellis SJ, Woolf EA, Tartaglia LA 1997 Cloning and characterization of an uncoupling protein homolog. Diabetes 46:900-906

53. Fleury C, Neverova M, Collins S, Raimbault S, Champigny O, Lévi-Meyrueis C, Bouillaud F, Seldin MF, Surwit RS, Ricquier D, Warden CH 1997 Uncoupling protein-2: A novel gene linked to obesity and hyperinsulinemia. Nat Genet 15:269-272

54. Hesselink MK, Keizer HA, Borghouts LB, Schaart G, Kornips CF, Slieker LJ, Sloop KW, Saris WH, Schrauwen P 2001 Protein expression of UCP3 differs between human type 1 , type $2 \mathrm{a}$, and type $2 \mathrm{~b}$ fibers. FASEB J 15:1071-1073 